\title{
Frequency and source of prescription eyewear insurance coverage in Ontario: a repeated population-based cross-sectional study using survey data
}

\author{
Prem Nichani MSc, Graham E. Trope MB PhD, Yvonne M. Buys MD, Samuel N. Markowitz MD, \\ Sherif El-Defrawy MD PhD, Gordon Ngo MD, Michelle Markowitz OD, Ya-Ping Jin MD PhD
}

\section{Abstract}

Background: Insurance coverage may reduce cost barriers to obtain vision correction. Our aim was to determine the frequency and source of prescription eyewear insurance to understand how Canadians finance optical correction.

Methods: We conducted a repeated population-based cross-sectional study using 2003, 2005 and 2013-2014 Canadian Community Health Survey data from respondents aged 12 years or older from Ontario, Canada. In this group, the cost of prescription eyewear is not covered by the government unless one is registered with a social assistance program or belongs to a specific population. We determined the frequency and source of insurance coverage for prescription eyewear in proportions. We used survey weights provided by Statistics Canada in all analyses to account for sample selection, a complex survey, and adjustments for seasonal effect, poststratification, nonresponse and calibration. We compared unadjusted proportions and adjusted prevalence ratios (PRs) of having insurance.

Results: Insurance covered all or part of the costs of prescription eyewear for $62 \%$ of Ontarians in all 3 survey years. Of those insured, $84.1 \%-86.0 \%$ had employer-sponsored coverage, $9.0 \%-10.3 \%$ had government-sponsored coverage, and $5.7 \%-6.8 \%$ had private plans. Employer-sponsored coverage remained constant for those in households with postsecondary graduation but decreased significantly for those in households with less than secondary school graduation, from $67.0 \%$ (95\% confidence interval [Cl] 63.2\%-70.8\%) $(n=175000)$ in 2005 to $54.6 \%(95 \% \mathrm{Cl} 50.1 \%-59.2 \%)(n=123500)$ in 2013-2014. Government-sponsored coverage increased significantly for those in households with less than secondary school graduation, from $29.2 \%(95 \% \mathrm{Cl} 25.5 \%-$ $32.9 \%)(n=76400)$ in 2005 to $41.7 \%(95 \% \mathrm{Cl} 37.2 \%-46.1 \%)(n=93900)$ in 2013-2014. In 2013-2014, Ontarians in households with less than secondary school graduation were less likely than those with secondary school graduation to report employersponsored coverage (adjusted PR $0.79,95 \% \mathrm{Cl} 0.75-0.84$ ) but were more likely to have government-sponsored coverage (adjusted PR 1.27, 95\% Cl 1.06-1.53).

Interpretation: Sixty-two percent of Ontarians had prescription eyewear insurance in 2003, 2005 and 2013-2014; the largest source of insurance was employers, primarily covering those with higher education levels, whereas government-sponsored insurance increased significantly among those with lower education levels. Further research is needed to elucidate barriers to obtaining prescription eyewear and the degree to which affordability impairs access to vision correction.

n estimated $57 \%$ of Canadians aged 20 years or older (16.8 million people in $2019^{1}$ ) have some form of vision problem requiring optical correction; ${ }^{2}$ the proportion among Canadians aged 50 or older is $80 \% .^{2}$ In the United States, clinically important refractive errors similarly affect over half of Americans. ${ }^{3}$ An appropriate pair of eyeglasses is a simple means to correct vision problems caused by refractive errors. However, the affordability of eyeglasses and contact lenses, referred to as prescription eyewear, is a major public health concern. ${ }^{4-7}$ In Canada, the cost of a pair of prescription eyeglasses may be prohibitive, ranging from $\$ 240$ to $\$ 1000$ in retail stores. ${ }^{8}$
Competing interests: Sherif El-Defrawy reports research grant support from Alcon, outside the submitted work. Ya-Ping Jin reports research grant support from the Lindenfield Family Research Grant for this study, and from the Glaucoma Research Society of Canada and the Kensington Eye Institute, outside the submitted work. Yvonne Buys reports consulting fees from Allergan and Bausch \& Lomb, outside the submitted work. No other competing interests were declared.

This article has been peer reviewed.

Correspondence to: Ya-Ping Jin, yaping.jin@utoronto.ca

CMAJ Open 2021. DOI:10.9778/cmajo.20200104 
Uncorrected and undercorrected refractive errors are the primary causes of visual impairment worldwide. ${ }^{9-14}$ Robinson and colleagues ${ }^{15}$ reported that $71.8 \%$ of cases of visual impairment among Ontarians aged 40 or older are amenable to refractive correction. Aljied and colleagues ${ }^{16}$ found that $64 \%-$ $80 \%$ of cases of visual impairment among Canadians aged 45 or older are due to refractive error. Similar findings have been reported from the US and Australia. ${ }^{17-19}$

In Canada, the cost of prescription eyewear is not covered by provincial health insurance plans. Most Canadians must pay out of pocket or use an insurance plan to obtain optical correction. We previously reported that about $55 \%$ of Canadians in 2003 had insurance that covered all or part of the cost of prescription eyewear. ${ }^{20}$ However, the source from which Canadians obtain their prescription eyewear insurance and changes in coverage in recent years are unknown. We performed a study to determine the frequency and source of insurance coverage for prescription eyewear in Ontario and the time trend from 2003 to 2013-2014 to better comprehend how people finance these vision aids. Our data may assist public policy experts in the quest to eradicate avoidable visual impairment and associated medicosocial consequences. ${ }^{21-24}$

\section{Methods}

\section{Setting and design}

We conducted a repeated population-based cross-sectional study using survey data from Ontario, Canada, where the cost of prescription eyewear is not covered by the government unless one is registered with a social assistance program (e.g., Ontario Works, Ontario Disability Support Program, ${ }^{25,26}$ Non-Insured Health Benefits program) or belongs to a specific population (e.g., veterans, refugees, First Nations and Inuit $^{27-30}$ ).

\section{Data source and participants}

The Canadian Community Health Survey is a nationwide, cross-sectional, self-report telephone survey covering $98 \%$ of Canadians aged 12 years or older living in private dwellings. ${ }^{31}$ Survey participants are selected at random by Statistics Canada. ${ }^{31-33}$ The present study is an analysis of Ontario respondents from the 2003, 2005 and 2013-2014 Canadian Community Health Surveys. We selected this population because Ontario was the only province to participate in the optional module on prescription eyewear insurance in all 3 survey years.

\section{Outcome measures}

Our study outcome measures were the frequency and source of prescription eyewear coverage. We ascertained this information from the Canadian Community Health Survey question "Now, turning to your insurance coverage. Please include any private, government or employer-paid plans." Following this opening statement, participants were asked, "Do you have insurance that covers all or part of the costs of eyeglasses or contact lenses?"34-36 Those who responded "Yes" in the 2005 and 2013-2014 surveys were further asked: "Is it (1) a government-sponsored plan? (2) an employer- sponsored plan? and/or (3) a private plan?" 34,35 No question on source of insurance was asked in the 2003 survey.

\section{Other measures}

Participants responded to questions regarding their age, sex, ethnoracial background, immigration status, marital status, highest level of education in the household and total annual household income. Highest level of education in the household was categorized by Statistics Canada into 4 groups: less than secondary school graduation; secondary school graduation, no postsecondary; some postsecondary education; and postsecondary certificate or diploma, or university degree. ${ }^{35,37}$ We consolidated data on total household income into 3 approximately equal groups: below middle level $(<\$ 4000)$, middle level (\$40 000-\$79 999 in 2003 and 2005, and \$40 000$\$ 89999$ in 2013-2014) and above middle level $(\geq \$ 80000$ in 2003 and 2005, and $\geq \$ 90000$ in 2013-2014). ${ }^{34-36}$

\section{Statistical analysis}

We determined the frequency and source of prescription eyewear insurance coverage. We calculated the frequency of coverage as the proportion of respondents who reported having insurance among all respondents. We computed the proportion of source of insurance as the proportion of respondents who reported having employer-sponsored (or governmentsponsored or private plan) coverage among all respondents who reported having insurance. We examined factors associated with having insurance coverage with prevalence ratios (PRs) derived from the log-Poisson regression model with robust variance estimation. ${ }^{38,39}$ The odds ratio from the logistic regression model was not used because the occurrence of the studied outcomes was quite common (> 30\%). We excluded invalid responses (i.e., "Don't know," "Refusal" and "Not stated") to questions analyzed from our analyses. We used survey weights provided by Statistics Canada in all analyses to account for sample selection, a complex survey, and adjustments for seasonal effect, poststratification, nonresponse and calibration. ${ }^{31-33}$ Weighted data are more representative of the survey population and are required by Statistics Canada for reporting when producing population estimates. ${ }^{31-33} \mathrm{We}$ constructed $95 \%$ confidence intervals (CIs) using bootstrap weights provided by Statistics Canada.

\section{Ethics approval}

Informed consent was obtained by Statistics Canada from all study participants. The analysis of Statistics Canada data for this study was approved by the University of Toronto Health Sciences Research Ethics Board.

\section{Results}

The unweighted number of Canadian Community Health Survey respondents in Ontario was 42777 in 2003, 41766 in 2005 and 42553 in 2013-2014, representing response rates of $91.4 \%, 92.2 \%$ and $86.4 \%$, respectively. ${ }^{31-33}$ One respondent $(0.002 \%)$ in 2005 and 5 respondents $(0.01 \%)$ in $2013-$ 2014 reported having prescription eyewear coverage from 


\begin{tabular}{|c|c|c|c|c|c|c|}
\hline \multirow[b]{2}{*}{ Characteristic } & \multicolumn{2}{|c|}{2003} & \multicolumn{2}{|c|}{2005} & \multicolumn{2}{|c|}{ 2013-2014 } \\
\hline & $\begin{array}{l}\text { Frequency } \\
(n, 100 \text { 's })\end{array}$ & $\begin{array}{l}\text { Prevalence } \\
(95 \% \mathrm{CI}), \%\end{array}$ & $\begin{array}{l}\text { Frequency } \\
(n, 100 \text { 's })\end{array}$ & $\begin{array}{l}\text { Prevalence } \\
(95 \% \mathrm{Cl}), \%\end{array}$ & $\begin{array}{l}\text { Frequency } \\
(n, 100 \text { 's })\end{array}$ & $\begin{array}{l}\text { Prevalence } \\
(95 \% \mathrm{CI}), \%\end{array}$ \\
\hline Total & 62155 & $62.3(61.5-63.0)$ & 61846 & $62.1(61.3-62.8)$ & 68694 & $62.0(61.1-62.9)$ \\
\hline \multicolumn{7}{|l|}{ Age, yr } \\
\hline $12-19$ & 7936 & $69.2(67.3-71.1)$ & 8106 & $67.6(65.7-69.6)$ & 7887 & $67.4(65.2-69.6)$ \\
\hline 20-39 & 20982 & $62.0(60.6-63.4)$ & 19933 & $61.7(60.4-63.0)$ & 20729 & $60.5(58.8-62.1)$ \\
\hline $40-64$ & 27598 & 68.7 (67.6-69.9) & 28209 & $68.9(67.7-70.1)$ & 32367 & $70.7(69.2-72.1)$ \\
\hline $65-74$ & 3585 & $42.8(40.8-44.9)$ & 3437 & 40.9 (38.9-42.9) & 5013 & $44.5(42.5-46.5)$ \\
\hline$\geq 75$ & 2054 & 34.2 (32.1-36.3) & 2161 & $36.2(33.8-38.6)$ & 2697 & $34.9(32.9-36.8)$ \\
\hline \multicolumn{7}{|l|}{ Sex ${ }^{*}$} \\
\hline Female & 31452 & $61.7(60.7-62.8)$ & 30909 & $60.9(59.8-61.9)$ & 34727 & $61.3(60.0-62.5)$ \\
\hline Male & 30703 & $62.8(61.7-63.9)$ & 30937 & $63.3(62.3-64.3)$ & 33967 & $62.8(61.4-64.1)$ \\
\hline \multicolumn{7}{|c|}{ Highest education level in household } \\
\hline $\begin{array}{l}\text { Less than secondary } \\
\text { school graduation }\end{array}$ & 3151 & $43.2(41.0-45.5)$ & 2630 & $42.5(40.1-45.0)$ & 2273 & $37.4(34.6-40.2)$ \\
\hline $\begin{array}{l}\text { Secondary school } \\
\text { graduation }\end{array}$ & 7192 & $57.9(56.0-59.8)$ & 5493 & $55.9(53.8-57.9)$ & 6939 & $53.0(50.5-55.4)$ \\
\hline Some postsecondary & 3441 & $60.5(57.4-63.7)$ & 2852 & $58.9(55.3-62.5)$ & 1995 & $57.6(52.3-62.9)$ \\
\hline $\begin{array}{l}\text { Postsecondary school } \\
\text { graduation }\end{array}$ & 46137 & $65.7(64.8-66.6)$ & 46516 & $65.6(64.7-66.5)$ & 55656 & $66.1[65.1-67.1)$ \\
\hline \multicolumn{7}{|l|}{ Marital status } \\
\hline Married/common-law & 39382 & $66.0(65.1-66.9)$ & 39179 & $65.8(64.8-66.8)$ & 42938 & $67.2(66.1-68.3)$ \\
\hline Widowed & 1779 & $36.3(33.9-38.6)$ & 1714 & $36.3(33.8-38.8)$ & 1830 & $36.1(33.6-38.6)$ \\
\hline Separated/divorced & 3526 & $56.9(54.4-59.5)$ & 3480 & $57.0(54.3-59.6)$ & 4490 & $54.5(51.1-57.8)$ \\
\hline Single/never married & 17432 & $60.2(58.7-61.7)$ & 17458 & $59.8(58.5-61.1)$ & 19233 & $57.9(56.2-59.5)$ \\
\hline \multicolumn{7}{|l|}{ Household income $†$} \\
\hline Below middle level & 9285 & $41.6(40.2-43.0)$ & 8229 & $38.7(37.3-40.1)$ & 9682 & $38.2(36.4-40.0)$ \\
\hline Middle level & 20878 & $65.6(64.4-66.9)$ & 19785 & $64.2(64.2-62.8]$ & 25889 & $60.8(59.3-62.2)$ \\
\hline Above middle level & 24888 & 77.7 (76.5-78.9) & 28165 & $77.9(76.8-79.0)$ & 33123 & $77.3[76.1-78.5)$ \\
\hline \multicolumn{7}{|l|}{ Ethnic background $\ddagger$} \\
\hline White & 50286 & 64.7 (63.9-65.4) & 49700 & $64.4(63.6-65.1)$ & 51085 & $64.4(63.6-65.3)$ \\
\hline Non-White & 9579 & $52.2(50.0-54.4)$ & 10805 & $53.1(50.9-55.3)$ & 15140 & $54.3(52.0-56.6)$ \\
\hline Aboriginal & 689 & $72.4(67.1-77.6)$ & 1109 & $67.6(53.1-72.0)$ & 2015 & 71.7 (67.8-75.7) \\
\hline \multicolumn{7}{|l|}{ Immigrant status§ } \\
\hline Nonimmigrant & 45682 & $67.1(66.3-67.8)$ & 45926 & $66.3(65.6-67.1)$ & 49039 & $66.7(65.8-67.6)$ \\
\hline \multicolumn{7}{|l|}{ Immigrant } \\
\hline Within previous $9 \mathrm{yr}$ & 3056 & 41.7 (38.1-45.2) & 3581 & $45.4(41.8-49.0)$ & 3499 & $43.6(39.1-48.0)$ \\
\hline 10 yr or longer & 11762 & $54.8(53.0-56.5)$ & 12173 & $55.3(53.4-57.3)$ & 15187 & $55.0(52.9-57.1)$ \\
\hline \multicolumn{7}{|c|}{$\begin{array}{l}\text { Note: } \mathrm{Cl}=\text { confidence interval. } \\
\text { "Self-reported as female or male. } \\
\text { †Less than middle level = less than } \$ 40000 \text {; middle level = } \$ 40000-\$ 79999 \text { in } 2003 \text { and } 2005, \$ 40000-\$ 89999 \text { in 2013-2014; above middle level = } \$ 80000 \text { or more in } \\
2003 \text { and } 2005, \$ 90000 \text { or more in } 2013-2014 \text {. } \\
\text { łWhite: self-identification as White; non-White: self-identification with a group other than White or Aboriginal; Aboriginal: self-identification as First Nations (Status or } \\
\text { non-Status), Métis or Inuk (Inuit). } \\
\text { \$Nonimmigrant: born in Canada; immigrant: not born in Canada. }\end{array}$} \\
\hline
\end{tabular}


3 sources (employer-sponsored, government-sponsored and private plan). These rare cases were included in our analyses of source of insurance. Between 3\% and 5\% $(n=1137-2162)$ of respondents in the surveys did not have a valid answer to the question on prescription eyewear insurance and were excluded from our analyses.

Overall, $62 \%$ of Ontarians aged 12 or older were covered in part or in full for the costs of prescription eyewear in all 3 study years (Table 1). Of the 11.1 million people in this age group in the province in 2013-2014, 4.2 million (38\%) had no insurance coverage. Coverage was higher among those aged 12-19 and those aged 40-64, and was lower among those aged 65-74 and those aged 75 or older (Table 1). In 2013-2014, coverage among Ontarians aged 75 or older was about half of the coverage among those aged 40-64 (34.9\% v. 70.7\%).

Insurance coverage increased in parallel with increasing education level and increasing household income (Table 1). In terms of marital status, coverage was lowest for those who were widowed $(36.1 \%$ in 2013-2014, less than half the coverage among those who were married or in a common-law relationship, 67.2\%). In terms of ethnicity, Aboriginal Ontarians had the highest coverage $(71.7 \%$ in $2013-2014)$, followed by those who self-identified as White (64.4\% in 2013-2014). Immigrants had significantly lower insurance coverage than nonimmigrants; this was true even for those who had lived in Canada for 10 years or longer (Table 1 ).

\section{Source of funding}

In 2005 and 2013-14, the main source of funding among Ontarians with prescription eyewear coverage was employers

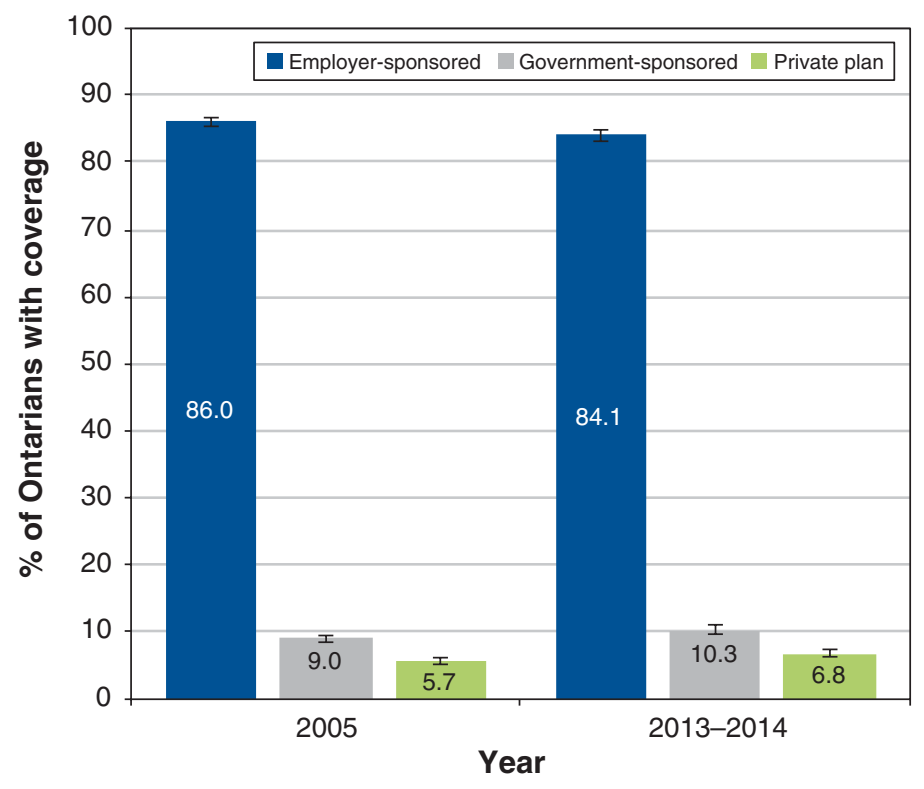

Figure 1: Proportion of Ontarians with prescription eyewear coverage in 2005 and 2013-2014, by source of funding. Data for 2003 were unavailable. Error bars represent $95 \%$ confidence intervals.
(84.1\% and $86.1 \%$, respectively), followed by government subsidies $(9.0 \%$ and $10.3 \%$, respectively) and private plans (5.7\% and 6.8\%, respectively) (Figure 1). Data for 2003 were unavailable.

In both years, among Ontarians with coverage, $87.0 \%$ of those in households with postsecondary education had employer-sponsored plans (Figure 2A). The proportion with employer-sponsored coverage decreased significantly between 2005 and 2013-2014 for those in households with less than secondary school graduation, from $67.0 \%$ (95\% CI $63.2 \%-$ $70.8 \%)(n=175000)$ to $54.6 \%(95 \%$ CI $50.1 \%-59.2 \%)(n=$ 123 500) (Figure 2A). It also decreased significantly for those with a total household income below middle level, from $63.5 \%$ (95\% CI $61.2 \%-65.8 \%$ ) to $53.1 \%$ (95\% CI $50.1 \%-$ $56.0 \%$ ) (Figure 2B).

The rate of government-sponsored coverage increased significantly between 2005 and 2013-2014 among Ontarians in households with less than secondary school graduation, from $29.2 \%(95 \%$ CI $25.5 \%-32.9 \%)(n=76400)$ to $41.7 \%(95 \%$ CI $37.2 \%-46.1 \%)(n=93$ 900) (Figure 3A). Governmentsponsored coverage also increased significantly among those with a household income below middle level, from $29.7 \%$ (95\% CI $27.5 \%-31.8 \%$ ) to $38.4 \%$ (95\% CI $35.4 \%-41.1 \%$ ) (Figure 3B).

After adjustment for the confounding effects of age, sex, household income, marital status, immigrant status and ethnoracial background, Ontarians in households with less than secondary school graduation were significantly less likely than those with secondary school graduation to have employer-sponsored insurance (adjusted PR 0.79, 95\% CI $0.75-0.84$ ) but were more likely to have government-sponsored insurance (adjusted PR 1.27, 95\% CI 1.06-1.53) in 2013-2014 (Table 2). Missing values for adjusted covariates ranged from 0 (for age and sex) to 1508 (for ethnicity).

\section{Interpretation}

We found that $62 \%$ of Ontarians aged 12 years or older had prescription eyewear insurance in 2003, 2005 and 2013-2014. The largest source of insurance was employers, followed by government subsidies and private plans. Employersponsored insurance coverage primarily covered people in households with postsecondary school graduation. It was significantly lower in 2013-2014 than in 2005 among those in households with less than secondary school graduation. In contrast, the rate of government coverage increased significantly among people in households with less than secondary school graduation over the study period. This trend may be partly due to updated and more inclusive financial eligibility criteria. ${ }^{8,40}$ In $2013-$ 2014, more than 4 million Ontarians had no prescription eyewear insurance at all, which 
A

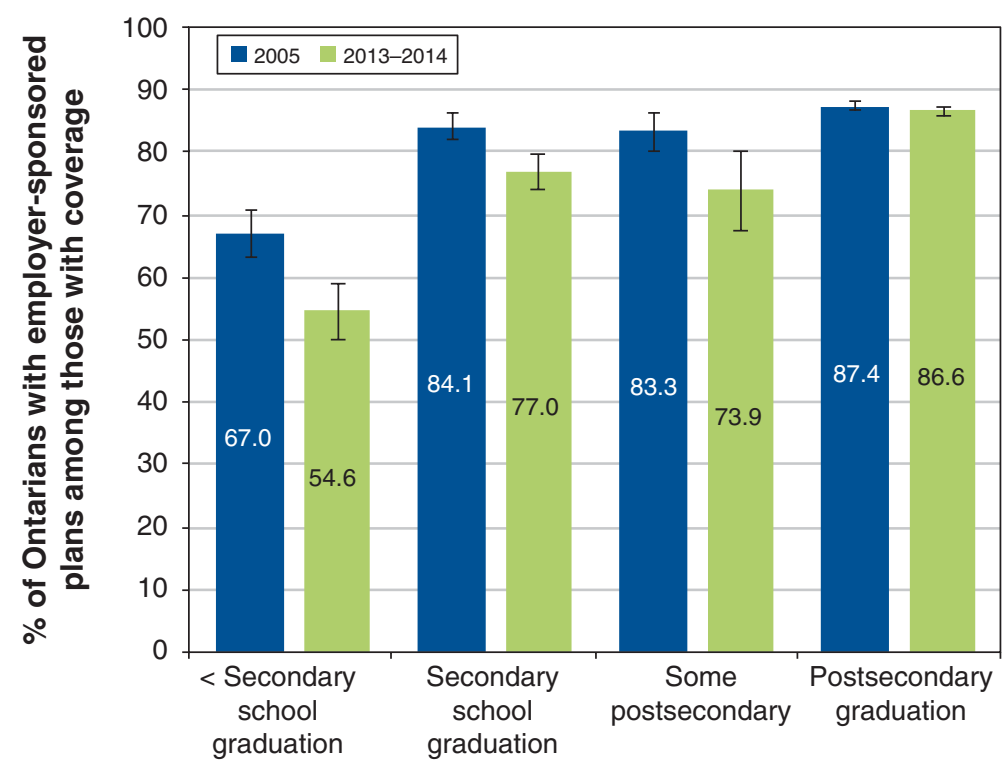

Highest level of education in household

B
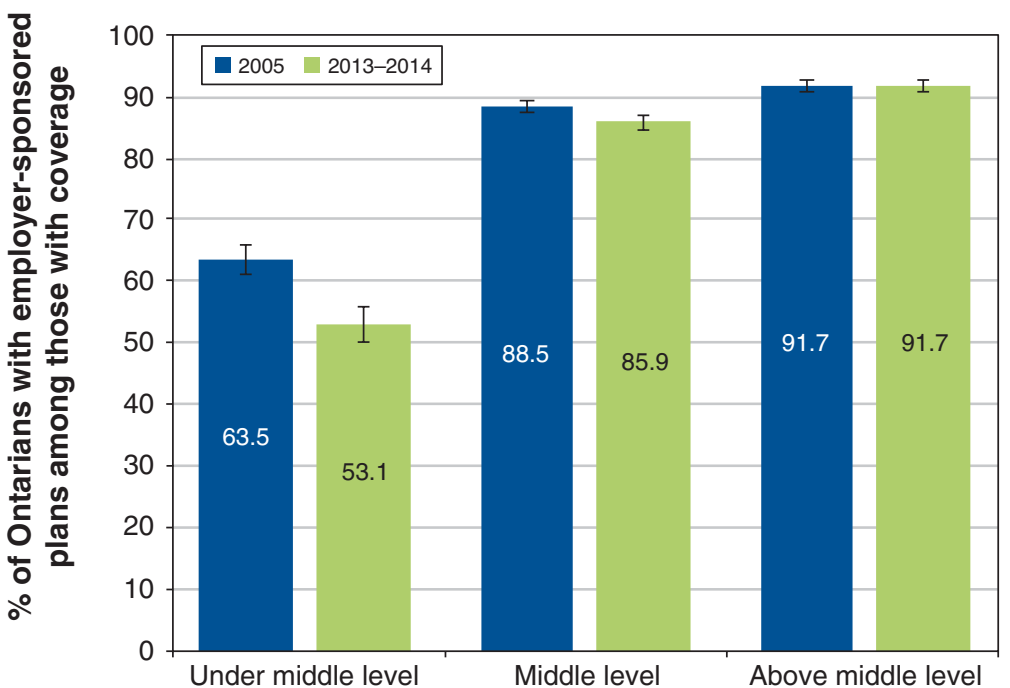

Household level of income ance, including coverage for eyewear, among retirees in Ontario declined between 2005 and 2013-2014. Using self-reported data from the US National Health Interview Survey, Varadaraj and colleagues ${ }^{6}$ reported that, in $2008-2016,15 \%-20 \%$ of Americans aged 18 or older had vision insurance (coverage for routine eye examinations, prescription lenses and frames) obtained through employment or via government programs such as Medicaid, or purchased directly. This rate is much lower than the $62 \%$ of Ontarians who were covered by an insurance plan in the present study. However, differences in survey questions ("[Do you have] a single service plan for vision care?" in the US study v. "Do you have insurance that covers all or part of the costs of eyeglasses or contact lenses?" in our study), the age group studied ( $\geq 18 \mathrm{yr}$ in the US study v. $\geq 12 \mathrm{yr}$ in our study) and US national versus Ontario provincial coverage make it difficult to comment on the disparity. $\mathrm{Li}$ and colleagues ${ }^{42}$ studied adults aged 40-64 years using Behavioural Risk Factor Surveillance System Vision Module data and found that $59.4 \%$ of Americans in 8 states had vision insurance in 2008, compared to $59.5 \%$ of working-age Canadians nationwide in $2003^{20}$ and $68.9 \%$ in Ontario in 2005 in the present study. Accordingly, coverage among those of working age seems to be similar in Canada and the US. We are not aware of prior studies reporting on the source of prescription eyewear insurance.

Although a small proportion (11\% in 2013-2014 in the current study) of people who have no insurance coverage for prescription eyewear may be able to afford it given their higher household income, the majority may face challenges related to cost. An inability to pay for the eye examination, lenses and frames may pose major barriers to obtaining needed vision correction, particularly among those with lower education levels, older adults, those who are widowed and immigrants. ${ }^{43-45}$ This is a paradox given that a previous study showed that these groups need eyeglasses the most. ${ }^{2}$ An eye examination is the necessary first step to prescription correction. In a previous study, the proportion of Ontarians who indicated cost as a reason 


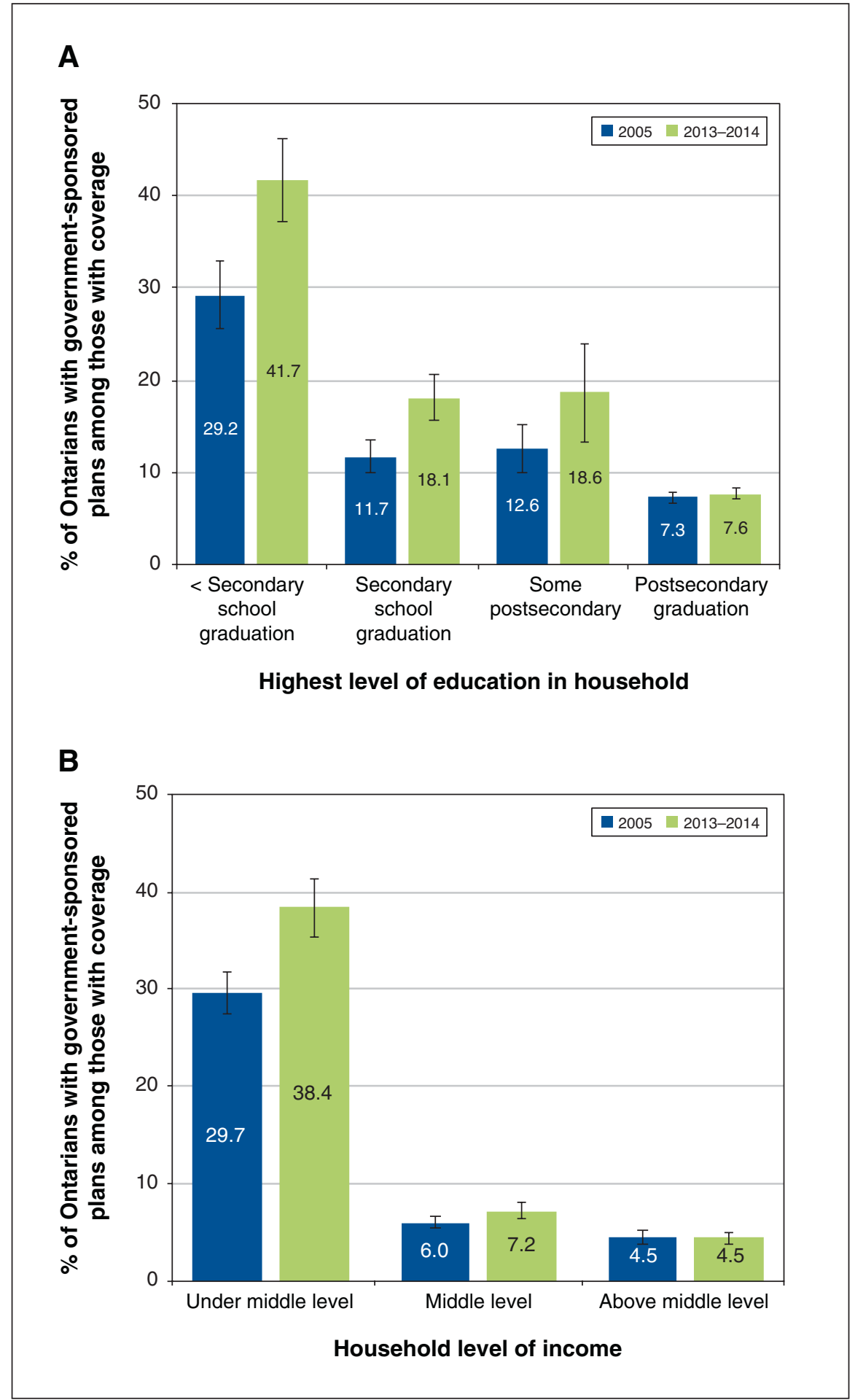

Figure 3: Proportion of Ontarians with prescription eyewear coverage who had governmentsponsored plans in 2005 and 2013-2014, by the highest level of education attained in the household (A) and total household income (B). Data for 2003 were unavailable. Error bars represent $95 \%$ confidence intervals.

for not having eye examinations was greater among those aged 20-64 who did not have government-insured eye examinations than among those aged less than 20 years or 65 or older with government coverage. ${ }^{2}$ This shows that the cost of an eye examination is the first hurdle on the path to obtaining prescription eyewear. ${ }^{46}$

Many large corporations find that the burden of providing health insurance for their workers seriously affects their ability to compete globally. ${ }^{47}$ Some smaller companies have eliminated their health insurance entirely or require greater contributions from the insured worker. ${ }^{47,48}$ Currently, financial deficits in health care budgets exist in almost every Canadian province; expanding employer-sponsored or government-sponsored prescription eyewear coverage therefore seems unlikely to occur. However, maintaining the current funding model will mean that $38 \%$ of Ontarians will remain uninsured, perpetuating cost barriers for those with visual impairment and impeding many Canadians from obtaining needed vision correction. We therefore call for politicians, policy-makers, governments and researchers to develop innovative solutions to help remedy the widespread need for optical correction.

\section{Limitations}

Study limitations include the use of self-reported data, which may be affected by recall and social desirability biases. Using collateral information such as social assistance data to validate self-reported government-sponsored coverage for prescription eyewear is challenging. ${ }^{40,49,50}$ Second, given the Canadian Community Health Survey sampling design, our findings apply only to Ontarians living in private dwellings, that is, a rented or owned property. ${ }^{20}$ Third, owing to survey question changes by Statistics Canada, the 2013-2014 survey is the last one with data on prescription eyewear insurance from Ontario, which made it difficult to examine coverage after this period. Last, the Canadian Community Health Survey did not elicit information on refractive surgery, the amount of coverage for prescription eyewear, whether copayments are required when using an insurance plan, or whether affordability or the lack of insurance was a perceived barrier to obtaining optical correction. We were therefore unable to address these issues. 


\begin{tabular}{|c|c|c|}
\hline \multirow[b]{2}{*}{ Variable } & \multicolumn{2}{|c|}{ Adjusted PR $(95 \% \mathrm{Cl})$} \\
\hline & $\begin{array}{l}\text { Employer-sponsored } \\
\text { insurance } †\end{array}$ & $\begin{array}{l}\text { Government-sponsored } \\
\text { insuranceł }\end{array}$ \\
\hline \multicolumn{3}{|l|}{ Age, yr } \\
\hline $12-19$ v. $40-64$ & $1.31(1.13-1.52)$ & $0.67(0.63-0.72)$ \\
\hline 20-39 v. 40-64 & $0.95(0.91-0.99)$ & $0.72(0.66-0.77)$ \\
\hline $65-74$ v. $40-64$ & $0.59(0.57-0.61)$ & $0.85(0.68-1.05)$ \\
\hline$\geq 75$ v. $40-64$ & $0.47(0.39-0.56)$ & $1.02(0.72-1.45)$ \\
\hline Male v. female sex & $0.98(0.93-1.03)$ & $1.00(0.97-1.04)$ \\
\hline \multicolumn{3}{|l|}{ Highest level of education in household } \\
\hline $\begin{array}{l}\text { Less than secondary school graduation } \\
\text { v. secondary school graduation }\end{array}$ & $0.79(0.75-0.84)$ & $1.27(1.06-1.53)$ \\
\hline $\begin{array}{l}\text { Some postsecondary school v. secondary } \\
\text { school graduation }\end{array}$ & $1.05(0.95-1.16)$ & $1.23(0.96-1.57)$ \\
\hline $\begin{array}{l}\text { Postsecondary school graduation } \\
\text { v. secondary school graduation }\end{array}$ & $1.12(1.08-1.16)$ & $0.84(0.67-1.05)$ \\
\hline \multicolumn{3}{|l|}{ Marital status } \\
\hline Widowed v. married/common-law & $0.88(0.72-1.07)$ & $0.82(0.77-0.87)$ \\
\hline $\begin{array}{l}\text { Separated/divorced v. married/ } \\
\text { common-law }\end{array}$ & $0.86(0.76-0.97)$ & $1.21(1.10-1.32)$ \\
\hline $\begin{array}{l}\text { Single/never married v. married/ } \\
\text { common-law }\end{array}$ & $0.70(0.60-0.81)$ & $1.60(1.30-1.96)$ \\
\hline \multicolumn{3}{|l|}{ Household income } \\
\hline Below middle level v. above middle level & $0.37(0.35-0.40)$ & $3.64(3.37-3.93)$ \\
\hline Middle level v. above middle level & $0.82(0.78-0.85)$ & $1.25(1.06-1.47)$ \\
\hline \multicolumn{3}{|l|}{ Ethnic background } \\
\hline Non-White v. White & $0.95(0.87-1.04)$ & $0.78(0.58-1.06)$ \\
\hline Aboriginal v. White & $0.91(0.83-0.99)$ & $3.26(2.81-3.79)$ \\
\hline Immigrant v. nonimmigrant & $0.87(0.86-0.89)$ & $0.69(0.64-0.74)$ \\
\hline \multicolumn{3}{|c|}{$\begin{array}{l}\text { Note: } \mathrm{Cl}=\text { confidence interval, } \mathrm{PR}=\text { prevalence ratio. } \\
\text { *All variables in the table were included in the regression model. Therefore, except for the variable being examined, all other } \\
\text { variables were adjusted for. } \\
\text { †Coverage provided by employers, unions, trade associations or student organizations, which usually have group policy numbers } \\
\text { by which insured people in the affiliated organization can be identified. The unweighted sample sizes were } 19085 \text { (insured) and } \\
35056 \text { (total). } \\
\text { †Government subsidies provided to those registered with specific programs (e.g., Ontario Works, Ontario Disability Support } \\
\text { Program, Non-Insured Health Benefits program) or who identify with specific populations (e.g., veterans, refugees, First Nations, } \\
\text { Inuit). The unweighted sample sizes were } 3203 \text { (insured) and } 19174 \text { (total). }\end{array}$} \\
\hline
\end{tabular}

\section{Conclusion}

We found that $38 \%$ of Ontarians aged 12 years or older between 2003 and 2013-2014 did not have insurance coverage for prescription eyewear and may thus be vulnerable to cost barriers associated with obtaining prescription eyewear. Among those insured, employers were the largest source of insurance, primarily covering people in households with postsecondary school graduation, whereas government subsidies were primarily provided to people in households with less than secondary school graduation. Further research is needed to elucidate barriers to obtaining prescription eyewear and the degree to which affordability impairs access to vision correction.

\section{References}

1. Population estimates on fuly 1st, by age and sex: Table 17-10-0005-01. Ottawa: Statistics Canada; 2019. Available: www150.statcan.gc.ca/t1/tbl1/en/cv.action?pid $=1710000501$ (accessed 2018 June 10).

2. Perruccio AV, Badley EM, Trope GE. A Canadian population-based study of vision problems: assessing the significance of socioeconomic status. Can $7 \mathrm{Oph}-$ thalmol 2010;45:477-83.

3. Vitale S, Ellwein L, Cotch MF, et al. Prevalence of refractive error in the United States, 1999-2004. Arch Ophthalmol 2008;126:1111-9.

4. Gupta P, Majithia S, Fenwick EK, et al. Rates and determinants of eyecare utilization and eyeglass affordability among individuals with visual impairment in a multiethnic population-based study in Singapore. Transl Vis Sci Technol 2020;9:11.

5. van Staden D. The universal eye health imperative for Canada: an inescapable reality of unmet need. Can 7 Public Health 2020;111:627-30.

6. Varadaraj V, Frick KD, Saaddine JB, et al. Trends in eye care use and eyeglasses affordability: the US National Health Interview Survey, 2008-2016. fAMA Ophthalmol 2019;137:391-8. 
7. Jin YP, Trope GE. Eye care utilization in Canada: disparity in the publicly funded health care system. Can 7 Ophthalmol 2011:46:133-8.

8. Hong CJ, Trope GE, Buys YM, et al. Does government assistance improve utilization of eye care services by low-income individuals? Can 7 Opbthalmol 2014;49:320-5.

9. Qiu M, Wang SY, Singh K, et al. Racial disparities in uncorrected and undercorrected refractive error in the United States. Invest Ophthalmol Vis Sci 2014; 55:6996-7005.

10. Rosman M, Wong TY, Tay WT, et al. Prevalence and risk factors of undercorrected refractive errors among Singaporean Malay adults: the Singapore Malay Eye Study. Invest Ophthalmol Vis Sci 2009;50:3621-8.

11. Liou HL, McCarty CA, Jin CL, et al. Prevalence and predictors of undercorrected refractive errors in the Victorian population. Am 7 Ophthalmol 1999;127:590-6.

12. Bourne RRA, Stevens GA, White RA, et al.; Vision Loss Expert Group. Causes of vision loss worldwide, 1990-2010: a systematic review. Lancet Glob Health 2013;1:339-49

13. Flaxman SR, Bourne RRA, Resnikoff S, et al.; Vision Loss Expert Group of the Global Burden of Disease Study. Global causes of blindness and distance vision impairment 1990-2020: a systematic review and meta-analysis. Lancet Glob Health 2017;5:e1221-34.

14. Sabanayagam C, Cheng CY. Global causes of vision loss in 2015: Are we on track to achieve the Vision 2020 target? Lancet Glob Health 2017;5:e1164-5.

15. Robinson B, Feng Y, Woods CA, et al. Prevalence of visual impairment and uncorrected refractive error - report from a Canadian urban population-based study. Ophthalmic Epidemiol 2013;20:123-30.

16. Aljied R, Aubin MJ, Buhrmann R, et al. Prevalence and determinants of visual impairment in Canada: cross-sectional data from the Canadian Longitudinal Study on Aging. Can 7 Ophthalmol 2018;53:291-7.

17. Chou CF, Cotch MF, Vitale S, et al. Age-related eye diseases and visual impairment among U.S. adults. Am 7 Prev Med 2013;45:29-35.

18. Fisher DE, Shrager S, Shea SJ, et al. Visual impairment in white, Chinese, Black and Hispanic participants from the Multi-Ethnic Study of Atherosclerosis cohort. Ophthalmic Epidemiol 2015;22:321-32.

19. Chia EM, Wang JJ, Rochtchina E, et al. Impact of bilateral visual impairment on health-related quality of life: the Blue Mountains Eye Study. Invest Ophthalmol Vis Sci 2004;45:71-6.

20. Ngo G, Trope G, Buys Y, et al. Significant disparities in eyeglass insurance coverage in Canada. Can 7 Ophthalmol 2018;53:260-5.

21. Hong T, Mitchell P, Burlutsky G, et al. Visual impairment and the incidence of falls and fractures among older people: longitudinal findings from the Blue Mountains Eye Study. Invest Ophthalmol Vis Sci 2014;55:7589-93.

22. Kasuga $\mathrm{T}$, Aruga $\mathrm{F}$, Ono $\mathrm{K}$, et al. Visual impairment as an independent risk factor for falls in hospitalized patients. Can 7 Ophthalmol 2017;52:559-63.

23. Loriaut $\mathrm{P}$, Loriaut $\mathrm{P}$, Boyer $\mathrm{P}$, et al. Visual impairment and hip fractures: a case-control study in elderly patients. Ophthalmic Res 2014;52:212-6.

24. Schlenker MB, Thiruchelvam D, Redelmeier DA. Association of cataract surgery with traffic crashes. 7AMA Ophthalmol 2018:136:998-1007.

25. Health benefits: vision. Toronto: Ontario Ministry of Children, Community and Social Services; 2018. Available: www.mcss.gov.on.ca/en/mcss/programs/ social/odsp/income_support/odsp_vision.aspx (accessed 2019 Dec. 20).

26. How Ontario Works can help you: health benefits. Toronto: Ontario Ministry of Children, Community and Social Services; 2018. Available: www.mcss.gov. on.ca/en/mcss/programs/social/ow/help/benefits/health_benefits.aspx (accessed 2019 Dec. 20).

27. Vision care benefits. Ottawa: Government of Canada; 2019. Available: www. sac-isc.gc.ca/eng/1574179499096/1574179544527 (accessed 2019 Apr. 2).

28. Interim Federal Health Program: summary of coverage. Ottawa: Immigration, Refugees and Citizenship Canada; 2019. Available: www.canada.ca/en/ immigration-refugees-citizenship/services/refugees/help-within-canada/health -care/interim-federal-health-program/coverage-summary.html (accessed 2019 Dec 20).

20. Medical coverage. Toronto: Ontario Association of Optometrists; 2017. Available: www.optom.on.ca/OAO/Patients/Medical_Coverage/OAO/Patients/ Medical_Coverage.aspx (accessed 2019 Dec. 20).

30. Non-insured health benefits for First Nations and Inuit. Ottawa: Indigenous Services Canada; 2019. Available: www.sac-isc.gc.ca/eng/1572537161086/ 1572537234517 (accessed 2019 Dec. 20).

31. Canadian Community Health Survey (CCHS) annual component: user guide. 2014 and 2013-2014 microdata files. Ottawa: Statistics Canada; 2015. Cat no 82M0013X2016001. Available: https://gsg.uottawa.ca/data/teaching/soc/ cchs201314/CCHS_2014_2013-2014_User_Guide.pdf(accessed 2021 Jan. 25).

32. Canadian Community Health Survey (CCHS) cycle 2.1 (2003), public use microdata file (PUMF) documentation. Ottawa: Statistics Canada; 2005. Cat no 82M0013X2003000. Available: http://www.statcan.gc.ca/eng/statistical -programs/document/3226_D7_T9_V2-eng.pdf (accessed 2018 June 10).

33. Canadian Community Health Survey (CCHS) cycle 3.1 (2005), public use microdata file (PUMF) user guide. Ottawa: Statistics Canada; 2006. Cat no 82M0013X2006000. Available: http://www.statcan.gc.ca/eng/statistical -programs/document/3226_D7_T9_V3-eng.pdf (accessed 2018 June 10).

34. Canadian Community Health Survey (CCHS) 2005 (Cycle 3.1). Ottawa: Statistics Canada; 2006. Available: http://www.statcan.gc.ca/imdb-bmdi/instrument/ 3226_Q1_V3-eng.pdf (accessed 2018 June 10).
35. Canadian Community Health Survey (CCHS) 2013/14. Ottawa: Statistics Canada; 2015. Available: http://www.statcan.gc.ca/eng/statistical-programs/ instrument/3226_Q1_V11-eng.pdf (accessed 2018 June 10).

36. Canadian Community Health Survey (CCHS) 2003 (Cycle 2.1). Ottawa: Statistics Canada; 2004. Available: http://www.statcan.gc.ca/imdb-bmdi/instrument/ 3226_Q1_V2-eng.pdf (accessed 2018 June 10).

37. CCHS 2013-2014: data dictionary public use microdata file, 24-month. Ottawa: Statistics Canada; 2016. Available: http://sda.chass.utoronto.ca/sdaweb/dli2/cchs/ cchs2013-14/more_doc/2013-14/CCHS_2013-2014_DataDictionary_Freqs.pdf (accessed 2018 June 10).

38. Zou G. A modified Poisson regression approach to prospective studies with binary data. Am 7 Epidemiol 2004;159:702-6.

39. Barros AJD, Hirakata VN. Alternatives for logistic regression in cross-sectional studies: an empirical comparison of models that directly estimate the prevalence ratio. BMC Med Res Methodol 2003;3:21.

40. Ontario Works Directives. Toronto: Ontario Ministry of Children, Community and Social Services; 2017. Available: www.mcss.gov.on.ca/en/mcss/programs/ social/directives/ow/4 2 OW Directives.aspx (accessed 2020 Sept. 4).

41. Chan FKI, McGrail K, Majumdar SR, et al. Changes in employer-sponsored private health insurance among retirees in Ontario: a cross-sectional study. CMA7 Open 2019;7:E15-22.

42. Li YJ, Xirasagar S, Pumkam C, et al. Vision insurance, eye care visits, and vision impairment among working-age adults in the United States. $7 A M A$ Ophthalmol 2013;131:499-506.

43. Devoe JE, Baez A, Angier H, et al. Barriers to health care access for lowincome families. Ann Fam Med 2007;5:511-8.

44. Locker D, Maggirias J, Quiñonez C. Income, dental insurance coverage, and financial barriers to dental care among Canadian adults. 7 Public Health Dent 2011;71:327-34.

45. Jin Y, Hou Z, Zhang D. Determinants of health insurance coverage among people aged 45 and over in China: Who buys public, private and multiple insurance? PLoS One 2016;11:1-15.

46. Jin YP, Buys YM, Hatch W, et al. De-insurance in Ontario has reduced use of eye care services by the socially disadvantaged. Can 7 Ophthalmol 2012;47: 203-10.

47. Silverman MW. The crisis in health care: Is it an optometric concern? Optometry 2006;77:180-6.

48. Law MR, Daw JR, Cheng L, et al. Growth in private payments for health care by Canadian households. Health Policy 2013;110:141-6.

49. Liu SY, Trope GE, Buys YM, et al. Visual impairment and the Ontario Disability Support Program. Can 7 Ophthalmol 2020;55:212-20.

50. Ontario Disability Support Program - income support. Toronto: Ontario Ministry of Children, Community and Social Services; 2018. Available: https:// www.mcss.gov.on.ca/en/mcss/programs/social/directives/odsp/is/6_1_ODSP_ ISDirectives.aspx (accessed 2020 May 19).

Affiliations: Faculty of Medicine (Nichani), Institute of Health Policy, Management and Evaluation (Nichani), Department of Ophthalmology and Vision Sciences (Trope, Buys, Markowitz, El-Defrawy, Jin) and Dalla Lana School of Public Health (Jin), University of Toronto; Toronto Western Hospital (Trope, Buys, Markowitz), University Health Network; Kensington Eye Institute (El-Defrawy), Toronto, Ont.; Faculty of Medicine (Ngo), University of Western Ontario, London, Ont.; private practice (Markowitz), Toronto, Ont.

Contributors: Prem Nichani participated in data analysis, drafted and revised the manuscript, and prepared tables and figures under guidance. Ya-Ping Jin, Graham Trope, Yvonne Buys, Samuel Markowitz, Sherif El-Defrawy and Gordon Ngo conceived the study. Ya-Ping Jin designed the study, acquired and analyzed the data, and led the manuscript draft and revision. All of the authors contributed to data interpretation, revised the manuscript critically for important intellectual content, approved the final version to be published and agreed to be accountable for all aspects of the work.

Funding: This research was supported by funds to the Canadian Research Data Centre Network from the Social Sciences and Humanities Research Council, the Canadian Institutes of Health Research, the Canadian Foundation for Innovation and Statistics Canada.

Data sharing: Access to this third-party data set is through the Statistics Canada Research Data Centres (RDCs) Program, which has centres at universities across Canada. Research Data Centres are operated under the provisions of the Canadian Statistics Act, which states that persons retained under contract to perform special services under this act are deemed to be persons employed under this act while performing those services, in accordance with all the confidentiality rules. Anyone may apply to access the data by submitting a research proposal that justifies the need for access to confidential microdata to address a question that has relevance for the Canadian population. On approval, researchers undergo 
a deeming process, and a contract is granted. Thus, access to the data is granted on a need-to-know basis. For those interested in obtaining access to these data sets, detailed contact information and application processes to gain access and guidelines to use RDC data can be found at https:// www.statcan.gc.ca/eng/rdc/process.

Content licence: This is an Open Access article distributed in accordance with the terms of the Creative Commons Attribution (CC BY-NCND 4.0) licence, which permits use, distribution and reproduction in any medium, provided that the original publication is properly cited, the use is noncommercial (i.e., research or educational use), and no modifications or adaptations are made. See: https://creativecommons.org/licenses/ by-nc-nd/4.0/.

Acknowledgements: The authors acknowledge that the data used in this publication are from Statistics Canada's Ontario components of the 2003, 2005 and 2013-2014 Canadian Community Health Surveys.
They thank all participants of these surveys and the Statistics Canada staff who assisted in the survey data collection and management.

Prior presentation: The study abstract was presented at the Canadian Ophthalmological Society annual meeting, June 13-16, 2019, Québec City, Que., the Association for Research in Vision \& Ophthalmology annual meeting, Apr. 28-May 2, 2019, Vancouver, BC, the University of Toronto Department of Ophthalmology and Vision Sciences 61st Research Day, May 24, 2019, Toronto, Ont., and the University of Toronto Institute of Medical Science Summer Undergraduate Research Program 50th Annual Research Day, Aug. 15, 2018, Toronto.

Disclaimer: The opinions expressed do not represent the views of Statistics Canada or the Canadian Research Data Centre Network.

Supplemental information: For reviewer comments and the original submission of this manuscript, please see www.cmajopen.ca/content/9/1/ E224/suppl/DC1. 